\section{Simvastatin-Enriched Macro-Porous Chitosan-Calcium-Aluminate Scaffold for Mineralized Tissue Regeneration}

Fernanda Balestrero Cassiano ${ }^{1} \mathbb{D}$, Diana Gabriela Soares ${ }^{\circledR}$, Ester Alves

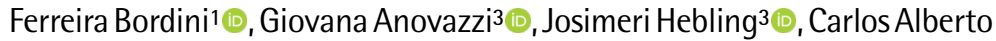
de Souza Costa 1 (1)
'Department of Physiology and Pathology, Araraquara School of Dentistry, UNESP Universidade Estadual Paulista, Araraquara, SP, Brazil ${ }^{2}$ Department of Operative Dentistry, Endodontics and Dental Materials, Bauru School of Dentistry, USP - Universidade de São Paulo, Bauru, SP, Brazil 3Department of Orthodontics and Pediatric Dentistry, Araraquara School of Dentistry, UNESP Universidade Estadual Paulista, Araraquara, SP, Brazil

Correspondence: Dr. Carlos Alberto de Souza Costa, Rua Humaitá, 1680, 14.801903 Araraquara, SP, Brasil. Tel: +55-16-3301-6477. e-mail: cas.costa@unesp.br

Key Words: guided tissue regeneration, simvastatin calcium aluminate, cell differentiation, dentin.

\section{Introduction}

Odontoblasts are specialized cells of the dental pulp that line the inner surface of the dentin. These cells play a fundamental role in the regeneration of the pulp-dentin complex exposed to stimuli of variable intensity. In a specific clinical situation of pulp exposure, a large amount of odontoblasts are lost, and thus biocompatible and bioactive direct pulp capping agents capable of stimulating local healing must be applied to the pulp wound (1). Calcium hydroxide and other similar synthetic materials, commonly used for pulp capping, are caustic products that cause an immediate layer of tissue necrosis, in which a number of death mesenchymal stem cells (MSCs) is present (2).

To overcome the limitations related to current pulp capping materials, tissue engineering has become a promising strategy for pulp-dentin complex regeneration. This research field applied to Dentistry has established different biological therapies that use biomaterials, such as scaffolds, to act as temporary substitutes of extracellular matrix (ECM) and to modulate tissue regeneration with no toxic effects to pulp cells (3). The processes of adhesion, proliferation and differentiation of human dental pulp cells (HDPCs) seeded on natural polymers scaffolds have been widely assessed due to the similarity of the polymeric matrix with glycosaminoglycans $(\mathrm{GAG})$, which are the main constituent of mineralized ECM $(1,4)$. Chitosan scaffolds have a polymeric chain consisting of free amine and hydroxyl groups that allows the chitosan molecule to be positively charged, making it more reactive towards other negatively charged molecules, such as collagen and proteoglycans $(5,6)$. In addition, this low-cost polymer has excellent biodegradability, biocompatibility and antimicrobial activity, thus presenting great potential to mediate tissue healing in therapies employed to maintain pulp vitality $(4,7)$.

To further enhance cell differentiation, variable mineral phases have been incorporated to scaffolds as the process seems to strongly induce osteoblastic and odontoblastic phenotypes, with consequent increase in the deposition of mineralized matrix in vitro and in vivo $(7,8)$. Our group has already demonstrated that chitosan-collagen scaffolds (8) and biomembranes (7) containing calcium-aluminate (AICa) particles increase the capability of HDPCs seeded onto those substrates to express odontoblastic phenotype, leading cells to deposit high amounts of calcium-rich matrix. Recently, the incorporation method of AICa to chitosan was improved, creating a chitosan scaffold with an organized AICa-incorporated macro-pore network (9). 
The authors showed that HDPCs seeded onto this innovative chitosan scaffold featured increased spread, proliferation and differentiation.

Another strategy to promote deposition of mineralized tissue is adding to the scaffold bioactive substances and molecules capable of signaling the differentiation of MSCs and attracting cells to the injured site $(1,3)$. The association of simvastatin to scaffolds has been proven to enhance the osteogenic and odontogenic potential of HDPCs and to accelerate mineralized tissue formation by activating the ERK $1 / 2$ and Smad1/2/3 signaling pathways, up-regulating the expression of alkaline phosphatase (ALP), dentin sialophosphoprotein (DSPP), and dentin matrix acidic phosphoprotein 1 (DMP-1) $(5,10-14)$. Soares et al. (10) demonstrated that the release of $0.1 \mathrm{uM}$ simvastatin from a chitosan scaffold induced chemotaxis of HPDCs from a 3D collagen matrix to its surface in an in vitro model of pulp exposure. The authors demonstrated that 3D culture in contact with the simvastatin-enriched scaffold also featured increased expressions of odontoblastic markers.

The aim of the present study was to develop and characterize a porous chitosan scaffold containing calcium

well as to assess the potential of this biomaterial inducing odontogenic differentiation of cultured HDPCs.

\section{Material and Methods} Obtaining HDPCS

After approval by the Human Ethics Committee of the Araraquara School of Dentistry - Unesp (Protocol \#30939314.5.0000.5416), the pulp of third molars extracted from a young donor (male, 18 years old) was collected to obtain a primary culture of HDPCs. The pulp tissue was submitted to enzymatic disaggregation in a type 1 collagenase solution ( $3 \mathrm{mg} / \mathrm{mL}$, Sigma-Aldrich, St. Louis, MO, USA) for $3 \mathrm{~h}$ at $37{ }^{\circ} \mathrm{C}$ and $5 \% \mathrm{CO}_{2}$. The obtained cells were cultured in complete Alpha Minimum Essential Medium (a-MEM, Gibco, Invitrogen, Carlsbad, CA, USA), supplemented with 10\% fetal bovine serum (FBS, Gibco), L-glutamine, and 1\% penicillin-streptomycin (Gibco). Cells in passage 3 through 6 were used in this study.

\section{Macro-Porous Chitosan-Calcium-Aluminate Scaffold (Chalca) Preparation}

Initially, 2\% chitosan powder (w/v; 75-85\% deacetylation, mol wt 310,000-375,000 Da; Sigma-Aldrich) was dissolved in a $2 \%$ aqueous acetic acid solution (SigmaAldrich) under constant magnetic stirring overnight. A 1\% suspension of calcium-aluminate cement (Sigma-Aldrich) was incorporated drop-wise under 1,000 rpm during $5 \mathrm{~min}$ to get the chitosan solution (1:5). Then, the formulations were poured into hermetically sealed 24-well plates (Kasvi, São José dos Pinhais, PR, Brazil) and subjected to phaseseparation at $-80^{\circ} \mathrm{C}$ overnight, followed by freeze-drying (Liotop L101, Liobras, Sao Carlos, Sao Paulo, Brazil) at $-56{ }^{\circ} \mathrm{C}$ overnight. The laboratorial preparation of CHAICa scaffolds was recently described in detail by Bordini et al. (9). The experimental scaffolds were coated with gold and evaluated concerning their morphology and composition by scanning electron microscopy (SEM) associated with dispersive energy spectroscopy (EDS) probe (JMS-6610V Scanning Microscope; JEOL, Tokyo, Japan), with an accelerating voltage of 12-15 kV.

\section{Incorporation of Simvastatin into Scaffold Structure}

Prior to the biological assays, cylindrical samples $(6 \mathrm{~mm}$ in diameter and $1 \mathrm{~mm}$ high) of CHAICa were prepared and immersed in 70\% ethanol solution for 30 min in vacuum for disinfection and to remove air bubbles from the structure. Then, the scaffolds were individually placed in a 24-well plate and washed with buffer solution (PBS; pH 7.4; Gibco) for 3 times to eliminate ethanol. Simvastatin (SV) was incorporated into the biomaterial as previously described by Soares et al. (10). Scaffolds were immersed in 1.0 and $0.5 \mu \mathrm{M}$ SV solutions prepared in PBS for $24 \mathrm{~h}$ at $37{ }^{\circ} \mathrm{C}$, since we observed in a previously study a release in around of 10\%, leading to an increase on the bioactive potential of plain chitosan scaffolds containing HDPCs (10). The following groups were stablished: CHAICa macro-porous chitosan-calcium-aluminate scaffolds; CHAICa-SV0.5 - macro-porous chitosan-calcium-aluminate scaffolds immersed into $0.5 \mu \mathrm{M} \mathrm{SV}$; CHAICa-SV1.0 - macroporous chitosan-calcium-aluminate scaffolds immersed into $1.0 \mu \mathrm{M} \mathrm{SV}$.

\section{Biological Assessment of Scaffolds}

HDPCs $\left(1 \times 10^{5}\right.$ cells) in culture medium (one drop, 3 $\mu \mathrm{L}$ ) were seeded onto scaffolds, and the scaffold/HDPCs sets were incubated for $30 \mathrm{~min}$ to allow initial cell adhesion. After, complete a-MEM was added to each well and replaced within $24 \mathrm{~h}$ by osteogenic medium (complete a-MEM $+50 \mu \mathrm{g} / \mathrm{mL}$ ascorbic acid $+5 \mathrm{mM}$ glycerophosphate; Sigma-Aldrich). During the 14-day incubation of the scaffold/HDPCs sets the culture medium was changed every $48 \mathrm{~h}$.

\section{Cell Viability}

Scaffolds $(n=2)$ were subjected to cell viability analysis within 14 days using the Live/Dead Viability/Cytotoxicity Kit (Invitrogen, Carlsbad, CA, USA). The culture medium was aspirated and the scaffolds/HDPCs set was rinsed with PBS, followed by incubation for $45 \mathrm{~min}$ in FBS-free a-MEM containing Calcein AM and Ethyl Homodimer-1 
(Invitrogen) probes at 1:1000 concentration. The surface of the scaffolds/HDPCs set was analyzed by fluorescence microscopy with sequential sections (Leica DM 5500B; Nussloch GmbH, Nussloch, Germany).

\section{Cell Adhesion and Spread}

Cell adhesion and spread on scaffolds surface was assessed after $14 \mathrm{~d}$ of culture by F-actin filament analysis. Scaffolds $(n=2)$ were washed in PBS, fixed in 4\% paraformaldehyde (PFA; Sigma-Aldrich) for $15 \mathrm{~min}$, and then incubated with the fluorescent probe Alexa Fluor Phalloidin 555 (1:50; Life Technologies, Carlsbad, CA, USA) for $30 \mathrm{~min}$. Samples were washed with PBS and nuclear counter-staining was obtained by incubation with DAPI mounting medium (ProLong, Thermo Fisher Scientific, Waltham, MA, USA). Analyses were performed under fluorescence microscope (Leica DM 5500B) to obtain representative images of each group.

\section{Deposition of Mineralized Matrix}

The Alizarin red technique was performed to determine the amount of mineralized matrix deposited in scaffolds after $14 \mathrm{~d}$ of culture $(n=6)$. HDPCs/ scaffolds sets were fixed in $70 \%$ ethanol at $4^{\circ} \mathrm{C}$ for $1 \mathrm{~h}$, followed by washing in deionized water and incubating for $15 \mathrm{~min}$ with Alizarin red solution ( $40 \mathrm{mM}, \mathrm{pH} 4.2$; Sigma-Aldrich). Successive washings with deionized water were performed, followed by the application of cetylpyridinium chloride (SigmaAldrich) for nodule dissolution and absorbance reading at 570 nm (Synergy H1, BioTek Instruments, Winooski, VT, USA). Scaffolds without cells were used as background control and the absorbance of the CHAICa group was considered as $100 \%$ staining.

\section{Real-Time PCR}

The expression of ALP, Col1A1, DMP-1, and DSPP was assessed by real-time PCR after $14 d$ of culture $(n=4)$.
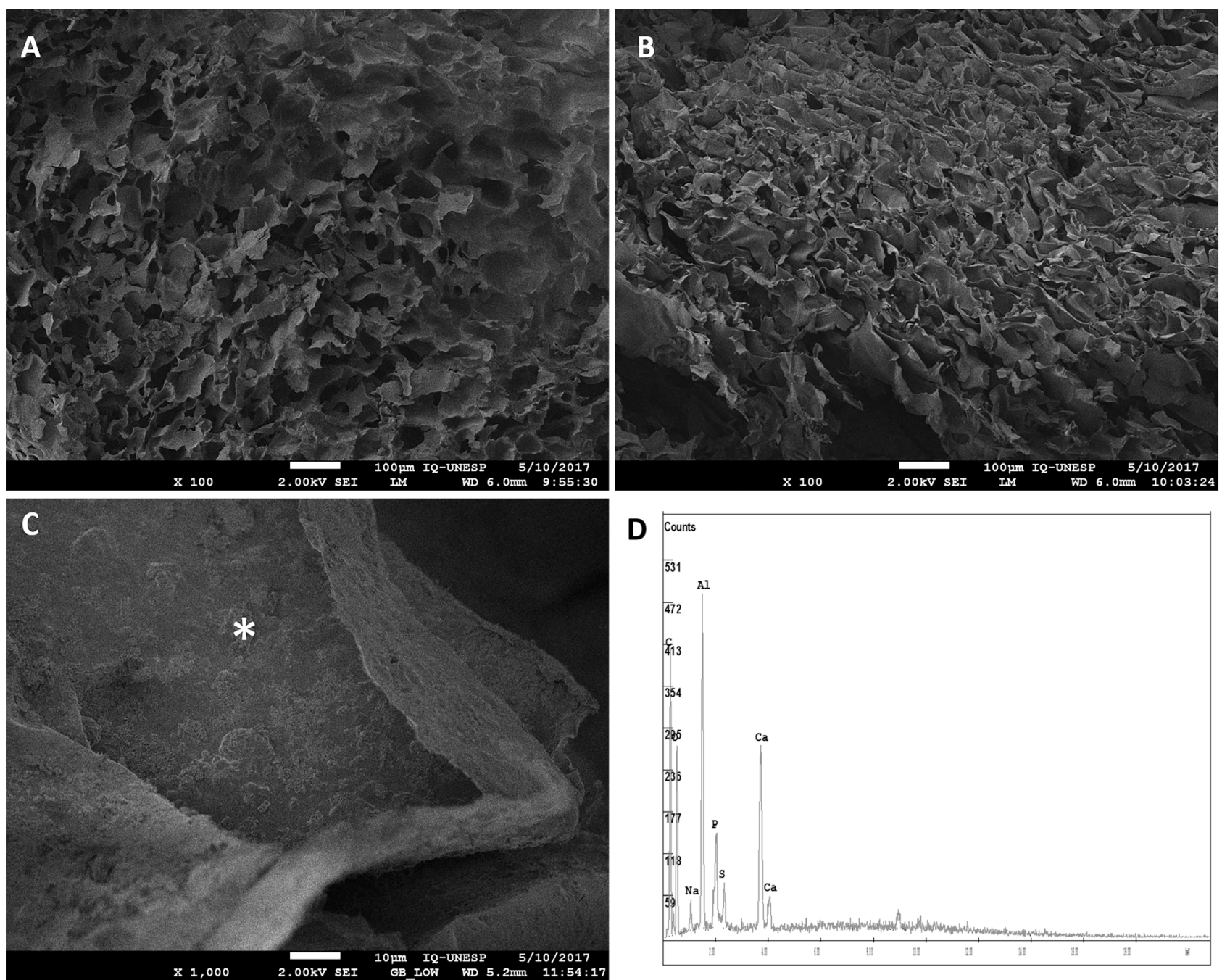

Figure 1. Scanning electron microscopy images and EDS composition analysis of CHAlCa. Surface (A) and a cross section (B) of the material (100x magnification). C: (1000× magnification): pore wall of the biomaterial. *EDS analysis (D) shows a peak in the aluminum and calcium elements incorporated in the chitosan matrix, in addition to the organic polymer components. 
For RNA extraction and cDNA synthesis, the RNaqueous ${ }^{\circledR}$ Micro Kit (Applied Biosystems, Foster City, CA, USA) and High Capacity cDNA Reverse Transcription Kit (Applied Biosystems), respectively, were used following the manufacturer's recommendations. Relative gene expression was analyzed on a StepOnePlus ${ }^{\text {TM }}$ Real-Time PCR System (Applied Biosystems) using the TaqMan assay (Applied Biosystems) according to the manufacturer's protocol. The $\beta$-actin gene was used as a constitutive gene. Data were calculated according to the $2 \Delta \Delta C T$ equation using the CHAICa group for data normalization.

\section{Statistical Analysis}

Two independent experiments were carried out to confirm the reproducibility of the results. Data were submitted to one-way ANOVA followed by Tukey's test to assess statistical differences between groups. Statistical inferences were taken at the 5\% level of significance.

\section{Results}

Morphological Characterization of ChitosanCalcium-Aluminate Scaffolds

The CHAICa group presented well distributed and organized macro-pore architecture throughout its structure (Fig. 1A,B) with embedded aluminum (AI) and calcium (Ca) microparticles identified by the EDS probe (Fig. 1C,D).

\section{Cell Viability, Adhesion, and Spread}

Viable cells were observed throughout the scaffolds surface by the green fluorescence of the Live/Dead cell viability test (Fig. $2 \mathrm{~A}-\mathrm{C}$ ). The incorporation of both SV doses into the organic matrix of the scaffolds did not cause toxic effects to HDPCs. The images of F-actin staining (Fig. 2D-F) showed adhered and scattered cells throughout the scaffold structure.

\section{Bioactive Potential of Simvastatin}

The presence of $1 \mu \mathrm{M} \mathrm{SV}$ in the CHAICa group enhanced the scaffolds bioactivity (Fig. 3). The Alizarin Red assay results (Fig. 3A) showed significant higher deposition of calcium-rich mineralized matrix by the CHAICa-SV1.0 scaffolds compared to the other experimental and control groups. Gene expression of the odontogenic markers ALP, Col1A1 and DMP-1 (Fig. 3B-D) increased significantly in HDPCs on the CHAICa-SV1.0 group in comparison to other groups.

\section{Discussion}

Several products and techniques capable of inducing stem cells differentiation and migration to damaged tissue sites have been proposed and assessed in the last decades (1). For regeneration of pulp-dentin complex, it is essential that scaffolds have similar structures to mineralized $\operatorname{ECM}(1,3)$.
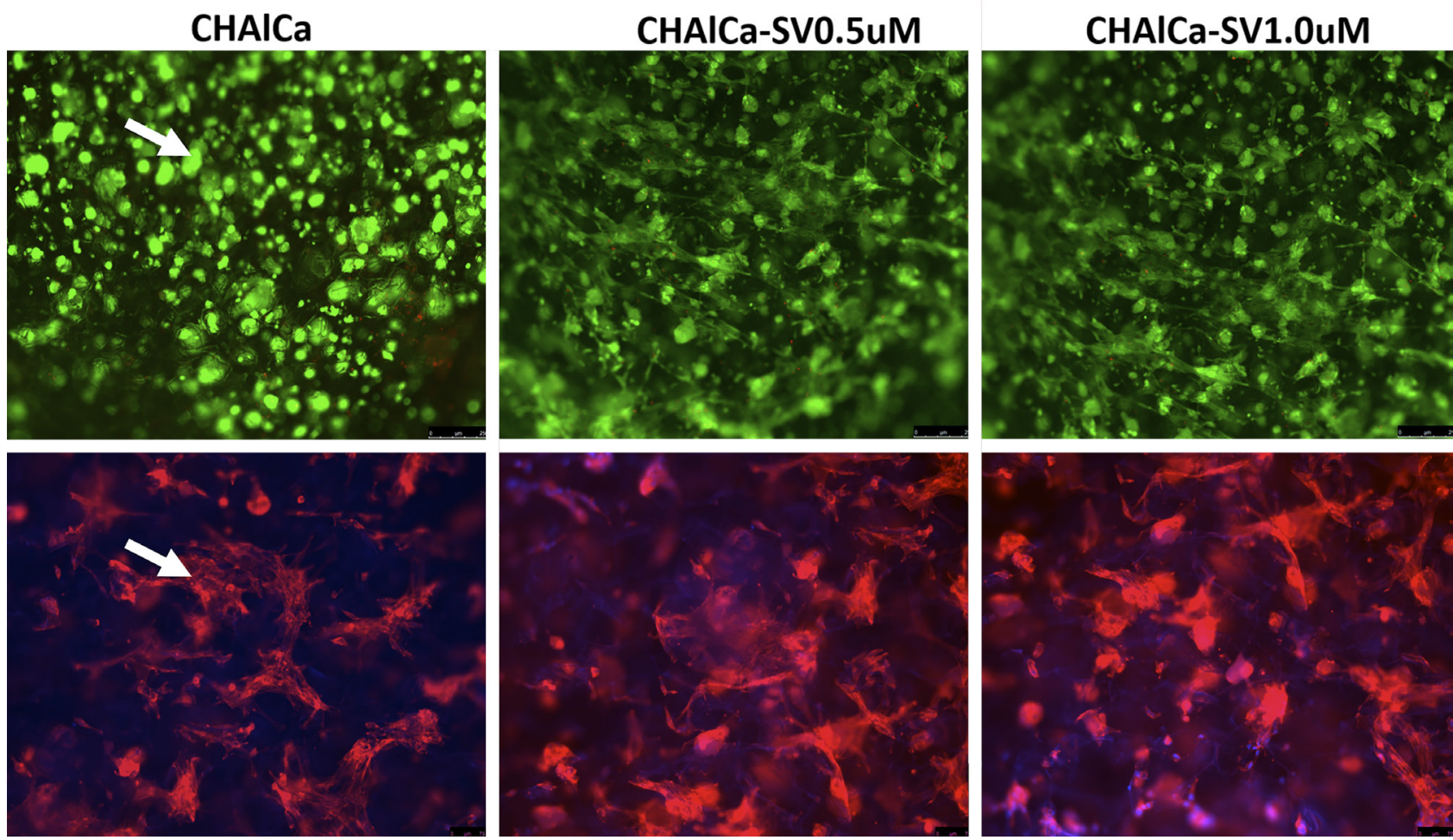

Figure 2. Fluorescence microscopy images of cell viability (Live/Dead). A-C: Viable cells are shown in green fluorescence (arrow; 20× magnification). D-F: Images of cell adhesion and scattering (F-actin) assays (arrow; 30× magnification). 
Thus, chitosan scaffolds have been the focus of a number of studies related to pulp-dentin regeneration since the structural composition of this polymer contains monomeric units of $\beta$-glucosamine and $\mathrm{N}$-acetylglucosamine that resemble glycosaminoglycans and proteoglycans present in dentin ECM $(4,8-10)$. However, in spite of improving the process of cell adhesion and differentiation, some authors have reported that chitosan scaffolds used for direct pulp capping induce the formation of a thin and irregular mineralized barrier (4). Therefore, the addition of different mineral phases and bioactive molecules into chitosan scaffolds to stimulate odontoblastic differentiation of dental pulp cells and to enhance the mineralized matrix deposition by such cells has been evaluated $(8,9)$. Therefore, in the present investigation the synergistic effect of macroporous chitosan-calcium-aluminate scaffolds containing SV on the odontogenic potential of HDPCs was assessed.

Previous studies demonstrated that calcium-aluminate microparticles play a positive role on the bioactive potential of a chitosan-collagen matrix by increasing HDPCs proliferation and differentiation as well as up-regulating DMP-1, DSPP, and ALP expression (8). The authors also reported that the incorporation of these microparticles in the chitosan-collagen matrix enhances the deposition of calcium-rich matrix by cultured HDPCs in comparison to plain chitosan-collagen matrix. Besides this bioactive potential, these biomaterials have low porosity due to the disorganized architecture achieved after phase-separation and freeze-drying, with cells adhering and spreading mainly onto its surface (8). To overcome this limitation, in the present study the collagen was excluded from the biomaterial and the method of AICa incorporation into the chitosan solution was modified, creating the $\mathrm{CHAICa}$ (9). Bordini et al. (9) demonstrated that the CHAICa scaffold allows cell infiltration into its structure in a higher degree than the plain chitosan scaffold. The authors also showed that CHAICa scaffold acts as a biocompatible and bioactive matrix, since cell proliferation, ALP activity, DSPP mRNA expression and calcium-rich matrix deposition were significantly enhanced in those HDPCs seeded onto its structure. The bioactive potential of CHAICa may be related to the hydration process of $\mathrm{AICa}$ cement when in contact with humidity, releasing $\mathrm{Ca}^{2}+$ and $\mathrm{Al}^{3}+$ ions over a long period of time (15). It has been shown that CHAICa scaffold is capable of releasing $\mathrm{Ca}^{2}+$ when immersed in water, leading to the establishment of an alkaline $(\mathrm{pH}=9.0)$
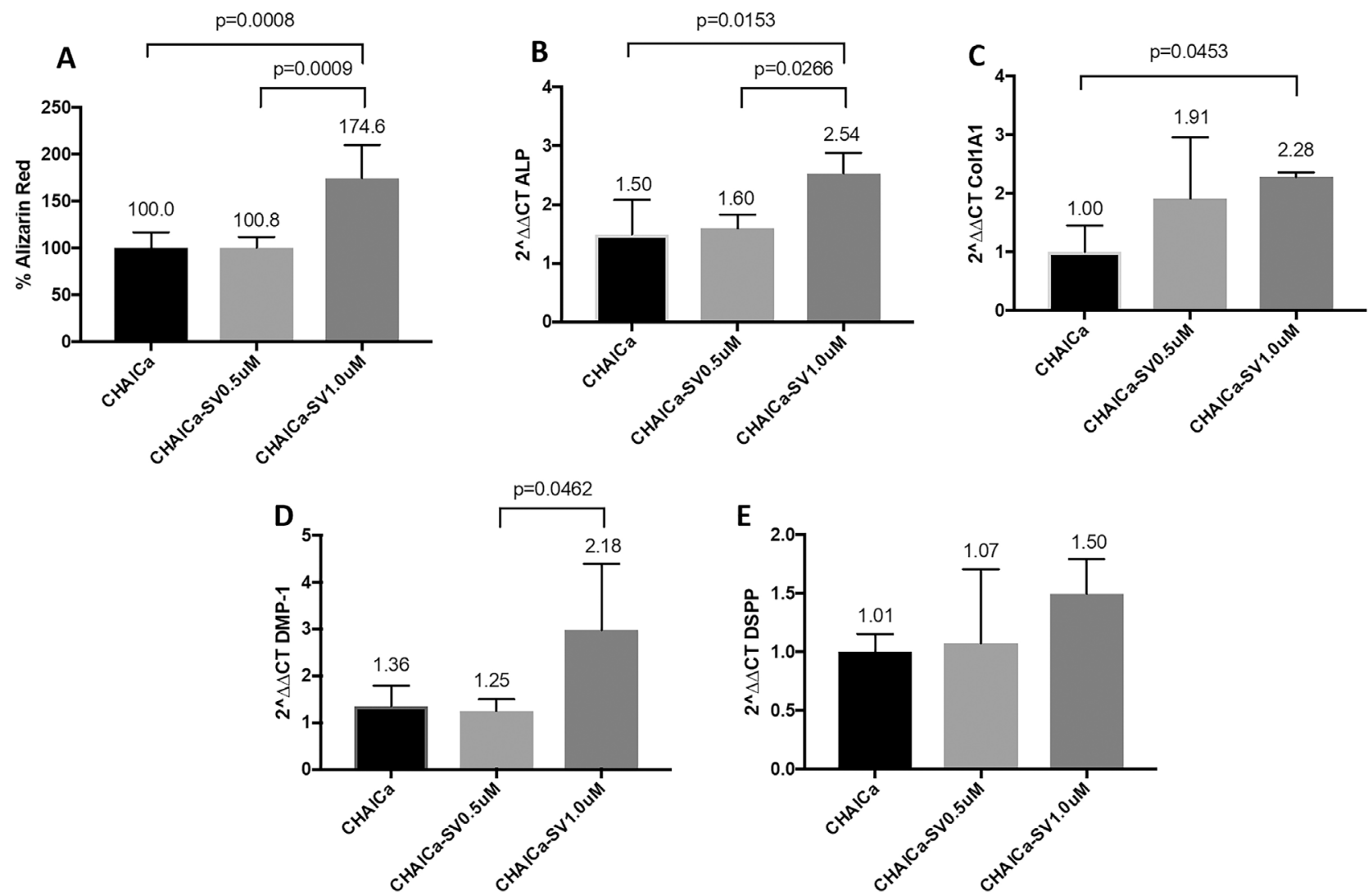

Figure 3. Quantitative analysis of cell differentiation markers. Mineralized matrix deposition (Alizarin red; A) and gene expression of the odontogenic markers ALP (B), Col1A1 (C), DMP-1 (D) and DSPP (E) by real-time PCR (p<0.05). 
environment within $24 \mathrm{~h}$, followed by a stabilization (pH $=7.8$ ) up to 7 days (9). A number of studies demonstrated that $\mathrm{Ca}^{2}+$ gradient exerts chemotactic, proliferative, and bioactive effects on MSCs $(7,8,15)$. In these studies, the authors reported that a slightly alkaline environment (pH 8.0-9.0) favors odontoblastic differentiation of pulp cells. Others also affirmed that the influx of $\mathrm{Ca}^{2}+$ on mesenchymal stem cells lead to SMAD 1/5/8 and ERK $1 / 2$ phosphorylation, associated with the expression of several proteins related with osteo/odontogenic differentiation, including DSPP, ALP and DMP-1 (16). Therefore, based on these positive biological properties of the macroporous chitosan scaffold containing calcium-aluminate demonstrated in previous as well as in the present studies, one may suggest that CHAICa scaffold has potential to be further tested as capping-agent of exposed pulp tissues.

The association of calcium-rich matrix with bioactive molecules has been proven to further increase the bioactive potential of mineralized scaffolds, accelerating new tissue formation $(5,9,10,13)$. Bordini et al. (9) reported that the odontogenic potential of HDPCs was significantly greater in cells seeded onto CHAICa scaffolds containing an osteogenic inductor (vitamin D) in comparison to $\Xi$ plain CHAICa scaffolds. Among the substances capable of modulating mineralization potential of precursor cells, statins have been considered a very interesting option because they accelerate bone repair in vivo (17).

Simvastatin (SV) is a relatively low-cost statin that has been widely assessed because of its capacity to regulate bone growth and tertiary dentin deposition in vitro and in vivo $(5,10,13,14,18)$. This drug induces odontoblasts cell differentiation and mineralized matrix deposition by activating the ERK1/2 and Smad1/2/3 signaling pathways (14), associated with an increase in BMP-2 expression, in a mechanism independent of the mevalonate pathway. However, since high concentrations of statins can impair cell differentiation, selecting the ideal dosage of this drug is essential to positively modulate tissue mineralization $(10,19)$. Soares et al. $(10)$ performed a dose-response assay to select a bioactive dosage of SV for HDPCs. The authors observed that 0.1 to $0.01 \mu \mathrm{M}$ SV exerted a positive effect on ALP activity and mineralized tissue deposition. Thus, a chitosan scaffold was immersed into 1.0 and $0.5 \mu \mathrm{M}$ SV solutions, and HDPCs seeded on 3D culture in contact with the chitosan scaffold containing the $1.0 \mu \mathrm{M}$ dose showed increased chemotactic effect and increased gene expression of DMP-1, DSPP, ALP, and Col1A1. Cells were then tested in a laboratorial model of pulp exposure performed in dentin discs, through which the authors could demonstrate the ability of SV-enriched chitosan scaffolds to modulate dentin regeneration by depositing large amounts of mineralized matrix on the biomaterial structure and dentin surface.
In view of the interesting data previously obtained by Soares et al. (10), in the present study the authors proposed the incorporation of SV into CHAICa by immersing the porous biomaterial in solutions of the drug. It was observed that both concentrations of SV added to CHAICa did not alter the cytocompatibility of such biomaterial, with viable cells showing similar adherence and spread over its porous structure. Nevertheless, only 1.0 $\mu \mathrm{M}$ SV had effective synergistic potential with $\mathrm{CHAICa}$ characterized by an enhanced ALP, DMP-1, and Col1A1 gene expressions in comparison to plain CHAICa, along with a 74.6\% increase in the calcium-rich matrix deposition. Low concentrations of SV tested in this study caused positive biological results, such as previously reported by Miyazawa et al. (12), who developed and assessed biodegradable hydrogels loaded with water-insoluble SV micelles. When in contact with pulp cells, the hydrogel released low dosages of SV capable of increasing ALP activity, calcium deposition as well as local BMP-2 secretion. The authors also demonstrated that when implanted in the subcutaneous connective tissue of mice, the SV-loaded hydrogel increased the deposition of calcium and dentin sialoprotein (12). Okamoto et al. (11) and Lee et al. (20) showed that HDPCs exposed to low SV concentrations exhibited potential for odontoblastic differentiation, with increased expression of DSPP and OCN as well as deposition of mineralized tissue both in vitro and in vivo. More recently, Soares et al. (13) observed that HDPCs exposed to lipopolysaccharides (LPS) had reduced expression of odontoblastic markers. However, the expression of ALP, DSPP and DMP-1, as well as calcium deposition was up-regulated when LPS-treated cells were treated with low concentrations of SV. The drug also reduced TNF- $a$ gene expression, confirming its potential of inducing mineralized matrix formation even in the presence of inflammation.

According to the methodology used in this research, one can conclude that the association of the three tested components (chitosan, calcium aluminate and simvastatin) had a positive and synergistic effect on cell differentiation and mineralized matrix deposition. Despite the limitations of this in vitro study and the fact that results obtained from laboratorial studies cannot be extrapolated to clinical situations, the scaffold formulation CHAICa-SV1.0 seems to be promising for dentin regeneration. Thus, further in vitro and in vivo studies with this innovative biomaterial are needed in order to determine whether it can be successfully employed for pulp-dentin complex regeneration in the near future.

\section{Resumo}

0 presente estudo avaliou o potencial odontogênico de células da polpa dental humana (HDPCs) em contato com scaffolds de quitosana contendo 
aluminato de cálcio (CHAICa) associado ou não à baixas dosagens de sinvastatina (SV). Scaffolds de quitosana receberam uma suspensão de aluminato de cálcio e foram imersos em soluções contendo a droga. Foram estabelecidos três grupos experimentais: scaffolds de quitosana e aluminato de cálcio (CHAICa - controle), scaffolds de quitosana-aluminato de cálcio com $0.5 \mu \mathrm{M}$ SV (CHAICa-SV0.5), e quitosana-aluminato de cálcio com 1.0 $\mu \mathrm{M}$ SV (CHAICa-SV1.0). A morfologia e composição foram avaliados por MEV e EDS, respectivamente. Após 14 dias do cultivo das HDPCs sobre os scaffolds, foram avaliados a viabilidade celular, adesão e espalhamento, deposição de matriz mineralizada e expressão gênica de marcadores odontogênicos. Observou-se que as partículas de aluminato de cálcio foram incorporadas à matriz de quitosana, a qual exibiu poros regulares distribuidos por toda sua estrutura. As dosagens selecionadas de sinvastatina foram biocompativeis com as HDPCs. A concentração de $1 \mu \mathrm{M}$ de SV induziu intensa expressão de fenótipo odontoblástico pelas HDPCs, demonstrando aumento da deposição de matriz mineralizada e maior expressão de ALP, Col1A1 e DMP-1. Portanto, podemos concluir que a incorporação de aluminato de cálcio e sinvastatina em scaffolds de quitosana apresentou um efeito sinérgico nas HDPCs, favorecendo a diferenciação celular e deposição de matriz mineralizada.

\section{Acknowledgements}

The authors would like to thank the São Paulo Research Foundation (FAPESP - grants \# 2016/15674-5, 2016/06704-8, and 2017/20181-0) and the Brazilian National Council for Scientific and Technological Development (CNPq - grant \# 408721/2018-9) for the financial support of this study.

\section{References}

1. Moussa DG, Aparicio C. Present and future of tissue engineering scaffolds for dentin-pulp complex regeneration. J Tissue Eng Regen Med 2019;13:58-75.

2. de Souza Costa CA, Hebling J, Scheffel DL, Soares DG, Basso FG, Ribeiro AP. Methods to evaluate and strategies to improve the biocompatibility of dental materials and operative techniques. Dent Mater 2014;30:769-84.

3. Galler KM, Eidt A, Schmalz G. Cell-free approaches for dental pulp tissue engieering. J Endod 2014;40:S41-45.

4. Li F, Liu X, Zhao S, Wu H, Xu HH. Porous chitosan bilayer membrane containing TGF- $\beta 1$ loaded microspheres for pulp capping and reparative dentin formation in a dog model. Dent Mater 2014;30:172181.

5. Gentile $\mathrm{P}$, Nandagiri VK, Daly J, Chiono V, Mattu C, Tonda-Turo $C_{\text {, }}$ et al. Localised controlled release of simvastatin from porous chitosan-gelatin scaffolds engrafted with simvastatin loaded PLGAmicroparticles for bone tissue engineering application. Mater Sci Eng C Mater Biol Appl 2016;59:249-257.

6. Rodríguez-Vázquez $M$, Vega-Ruiz $B$, Ramos-Zúñiga $R$, Saldaña-Koppel DA, Quiñones-Olvera LF. Chitosan and its potential use as a scaffold for tissue engineering in regenerative medicine. Biomed Res Int 2015:821279.

7. Soares DG, Rosseto HL, Basso FG, Scheffel DS, Hebling J, Costa CA.
Chitosan-collagen biomembrane embedded with calcium-aluminate enhances dentinogenic potential of pulp cells. Braz Oral Res 2016;30:e54.

8. Soares DG, Rosseto HL, Scheffel DS, Basso FG, Huck C, Hebling J, et al. Odontogenic differentiation potential of human dental pulp cells cultured on a calcium-aluminate enriched chitosan-collagen scaffold. Clin Oral Investig 2017;21:2827-2839.

9. Bordini EAF, Cassiano FB, Silva ISP, Usberti FR, Anovazzi G, Pacheco LE, Pansani TN, Leite MLAS, et al. Synergistic potential of 1a,25Dihydroxyvitamin D3 and calcium-aluminate chitosan scaffolds with dental pulp cells. CLOI Clin Oral Investig 2020;24:663-674.

10. Soares DG, Anovazzi G, Bordini EAF, Zuta UO, Silva Leite MLA, Basso FG, et al. Biological analysis of simvastatin-releasing chitosan scaffold as a cell-free system for pulp-dentin regeneration. J Endod 2018;44:971976.e1.

11. Okamoto $Y$, Sonoyama $W$, Ono $M$, Akiyama $K$, Fujisawa $T$, Oshima $M$, et al. Simvastatin induces the odontogenic differentiaton of human dental pulp stem cells in vitro and in vivo. J Endod 2009;35:367-372.

12. Miyazawa A, Matsuno T, Asano K, Tabata Y, Satoh T. Controlled release of simvastatin from biodegradable hydrogels promotes odontoblastic differentiation. Dent Mater J. 2015;34:466-474.

13. Soares DG, Zhang Z, Mohamed F, Eyster TW, de Souza Costa CA, Ma PX. Simvastatin and nanofibrous poly(I-lactic acid) scaffolds to promote the odontogenic potential of dental pulp cells in an inflammatory environment. Acta Biomater 2018;68:190-203.

14. Pei-YuChen, Jui-ShengSun, Yang-HweiTsuang, Ming-HongChen, PeiWeiWeng, Feng-HueiLin. Simvastatin promotes osteoblast viability and differentiation via Ras/Smad/Erk/BMP-2 signaling pathway. Nutr Res 2010;30:191-199.

15. Moraes PC, Marques ICS, Basso FG, Rossetto HL, Pires-de-Souza FCP, Costa CAS, Garcia LDFR. Repair of bone defects with chitosan-collagen biomembrane and scaffolds containing calcium aluminate cement. Braz Dent J 2017;28:287-295.

16. Li S, Hu J, Zhang G, Qi W, Zhang P, Li $P$, et al. Extracellular ca2+ promotes odontoblastic differentiation of dental pulp stem cells via bmp2-mediated smad1/5/8 and erk1/2 pathways. J Cell Physiol 2015;230:2164-2173.

17. Yun-Song Liu, Meng-Em Ou, Hao Liu, Ming Gu, Long-Wei Lv, Cong Fan, et al. The effect of simvastatin on chemotactic capability of SDF-1a and the promotion of bone regeneration. Biomaterials 2014;35:44894498.

18. Asl Aminabadi N, Satrab S, Najafpour E, Samiei M, Jamali Z, Shirazi S. A randomized trial of direct pulp capping in primary molars using MTA compared to 3Mixtatin: a novel pulp capping biomaterial. Tissue Eng Part A 2014;20:356-64.

19. M Kheirallah, H Almeshaly. Simvastatin, dosage, and delivery system for supporting bone regeneration, an update review. J Oral Maxillofac Surg Med Pathol 2016;28:2016-2019.

20. Lee SY, Min KS, Choi GW, Park JH, Park SH, Lee SI, et al. Effects of simvastatin and enamel matrix derivative on portland cement with bismuth oxide-induced growth and odontoblastic differentiation in human dental pulp cells. J Endod 2012;38:405-410.

Received November 5, 2019 Accepted April 28, 2020 